\title{
EFFECT OF GEOTEXTILE REINFORCEMENT ON SHEAR STRENGTH OF SANDY SOIL: LABORATORY STUDY
}

\author{
SidALI DENINE, NoUREDDINE DELLA \\ Laboratory of Material Science and Environment (LMSE), \\ Hassiba Benbouali University of Chlef - Algeria, e-mail: n.della@univ-chlef.dz

\section{RAWAZ DLAWAR MUHAMMED} \\ Laboratory Navier-Géotechnique, Ecole des ponts Paris Tech, France; \\ Departement of Geotechnical Engineering, Koya University, \\ Danielle Mitterrand Boulevard, Koya KOY45 AB64, Kurdistan Region, F.R. Iraq \\ Sadok Feia, Jean Canou, Jean-Claude Dupla \\ Laboratory Navier-Géotechnique, Ecole des ponts Paris Tech, France
}

\begin{abstract}
This paper presents results of a series of undrained monotonic compression tests on loose sand reinforced with geotextile mainly to study the effect of confining stress on the mechanical behaviour of geotextile reinforced sand. The triaxial tests were performed on reconstituted specimens of dry natural sand prepared at loose relative density $(\mathrm{Dr}=30 \%)$ with and without geotextile layers and consolidated to three levels of confining pressures 50, 100 and $200 \mathrm{kPa}$, where different numbers and different arrangements of reinforcement layers were placed at different heights of the specimens $(0,1$ and 2 layers). The behaviour of test specimens was presented and discussed. Test results showed that geotextile inclusion improves the mechanical behaviour of sand, a significant increase in the shear strength and cohesion value is obtained by adding up layers of reinforcement. Also, the results indicate that the strength ratio is more pronounced for samples which were subjected to low value of confining pressure. The obtained results reveal that high value of confining pressure can restrict the sand shear dilatancy and the more effect of reinforcement efficiently.
\end{abstract}

Key words: sand, behaviour, geotextile, undrained, confining pressure, excess pore pressure, strength ratio

\section{INTRODUCTION}

Chlef sand, which is widely distributed in the broad alluvial valley crossed by the Chlef River up to the zone of confluence of this river with the Fodda River, is generally medium soil in which more than $95 \%$ is particle size with some proportion of minerals as feldspar and quartz. Therefore it has suffered high risk environment, largely failure damage has been located after the last Chlef earthquake occurred on October 10, 1980 at $12 \mathrm{~h} 25$ GMT. As commonly observed on sandy soil, liquefaction has been marked on Chlef sand, inducing some effects on the soil foundations and earth structures, such as sand boils. Numerous research studies have been reported to the liquefaction of Chlef sand (Arab et al. [3]; Belkhatir et al. [8]; Della et al. [14]; Benghalia et al. [9]), where different factors that have an effect on the soil liquefaction phenomenon were studied (the initial relative density, void ratio, specimen preparation, specimen size, grading characteristics, stress history, preshearing and loading conditions). However, only a few works to study the effect of reinforcement on Chlef sand have been reported in the literature, in this work, an experimental investigation on the behaviour of reinforced Chlef sand with geotextile is presented. 


\section{LITERATURE REVIEW}

Liquefaction cases were observed during various earthquakes that occurred in Chlef and Algiers regions. Spectacular failures of natural slopes and liquefaction of saturated sands followed by large-scale subsidence were recorded during the 1980 Chlef earthquake. Due to the generation of high excess pore pressure on the silty sand soil, liquefied sand appeared at the ground level creating craters, moreover several other types of damage due essentially to the liquefaction of soil are observed (Benghalia et al. [9]). The existence of weak soils for building projects requires some improvement process, various types for improving soil are presented in the literature, and used in geotechnical engineering to reinforce soil and increase the factor of safety against possible failure (Nouri et al. [31]).

Nowadays, soil reinforcement technique has become a more frequently used process to improve soil than densification and chemical stabilization methods, this is why these latest methods require suitable field equipment, being difficult and very costly to achieve (Krishnaswamy and Isaac [24]). Several studies have investigated geosynthetics reinforced soil using different types of laboratory tests and numerical simulations, the results have generally revealed that reinforcement enhances the shear strength of reinforced sand in comparison with unreinforced sand (Al Refeai [2]; Ranjan et al. [33]; Yetimoglu and Salbas [36]; Consoli et al. [13]; Liu et al. [27]; Hamidi and Hooresfand [20]).

Although, many works reported in the literature demonstrated the efficiency of reinforcement regarding some factors such as: the reinforcement type effect, reinforcement content, soil properties and gradation, relative density, particle shape and other parameters (confining pressure, loading rate). Gray and Ohashi [18] found through a series of direct shear tests conducted on reinforced dry sand with different types of fibers that natural and synthetic fiber reinforcement exhibits a better performance than metal fibers. Krishnaswamy and Isaac [24] performed a series of cyclic triaxial tests to evaluate the liquefaction potential of sand with and without reinforcement. The results obtained confirmed that the reinforced sand can be a promising solution for increasing the safety against liquefaction potential of sand. Rajagopal et al. [32] carried out a large number of triaxial tests on granular soil encased in single and multiple geocells to study the influence of geocell confinement on the strength and stiffness behaviour of granular soils. Haeri et al.
[19] studied the mechanical behaviour of reinforced sand with geotextile under monotonic drained condition. They conducted 160 triaxial compression tests on unreinforced and reinforced Babolsar dry sand. They investigated the effect of some determining factors including geotextile layers, type and orientation of geotextiles and confining pressure. Nouri et al. [31] performed compression triaxial tests to evaluate the drained behaviour of reinforced Chlef sand with and without plastic layers. Test results demonstrated that reinforcement layers improved the deviator stress and the mechanical properties of soil. Venkatappa Rao et al. [35] performed a series of triaxial tests on sand reinforced with two forms of coir fiber reinforcement; they observed that sand reinforced with randomly distributed coir fiber exhibited a higher increase in strength parameters compared to layered coir fiber. Latha and Murthy [26] observed through undrained triaxial compression tests on reinforced sand that the geocell is a more effective form of reinforcement than the planar one. They reported also that the fiber form exhibits less improvement than planar or cellular forms. Hosseinpour et al. [21] analysed the behaviour of geotextile reinforced sand by the finite element method analysis to investigate the effect of particle size on the stress of reinforced sand. Liu et al. [27] conducted a series of ring shear tests to evaluate the static liquefaction of sand reinforced with propylene fiber. They found an increase in the peak shear strength with greater content of fiber. Naeini et al. [28] studied the interface shear strength of sand reinforced by geogrid which included the influence of sand silt mixtures on the shearing behaviour of reinforced silty sand. Furthermore, Naeini and Gholampoor [29] investigated the effect of geotextile layers on the cyclic behaviour of sand using triaxial apparatus. Test results indicated that liquefaction resistance increases with an increase of the number of geotextile layers.

Recently, reinforced sand laboratory studies have attracted more attention in the undrained loading conditions. Many studies have been intensively focused on the undrained response of fiber reinforced sand in mixing form (Chen [10]; Ahmed et al. [1]; Ibraim et al. [22]; Noorzad and Fardad Amini [30]; Erdogan and Altun [16]), where less attention was given to reinforced sand with planar form of reinforcement (Latha and Murthy [26]; Kim et al. [23]; Chen et al. [12]; Tuna et al. [34]).

The present study aims to evaluate the behaviour of unreinforced and reinforced sand under various levels of confining pressures. For this purpose, undrained monotonic triaxial tests on loose sand 
samples reinforced with geotextile layer forms were conducted.

\section{EXPERIMENTAL METHODS}

\subsection{MATERIALS}

\subsubsection{SOIL}

Natural Chlef sand (Algeria) was used in the present experimental investigation. It is alluvial material, extracted from the Chlef River banks (formerly known as El Asnam), from a depth of $2.5 \mathrm{~m}-6 \mathrm{~m}$. As known, soil liquefaction was remarked in this region during the last earthquake of October 1980, particularly in the flood plain areas of the river. As a result, numerous areas of sand boil were visible, and a large earthquake lake was formed southeast of the canyon mouth, where the Oued Fodda and Oued Chlef Rivers join (Fig. 1) (Durville and Méneroud [15]). The soil used is classified as poorly graded sand (SP) according to the Unified Soil Classification System (USCS). The particle size distribution curve obtained from sieve analysis and hydrometer tests is presented in Fig. 2. This soil contains a very small proportion of non-plastic silt. Figure 3 presents the microscopic images of sand showing particle mixtures of rounded medium grain shape. The physical properties of the

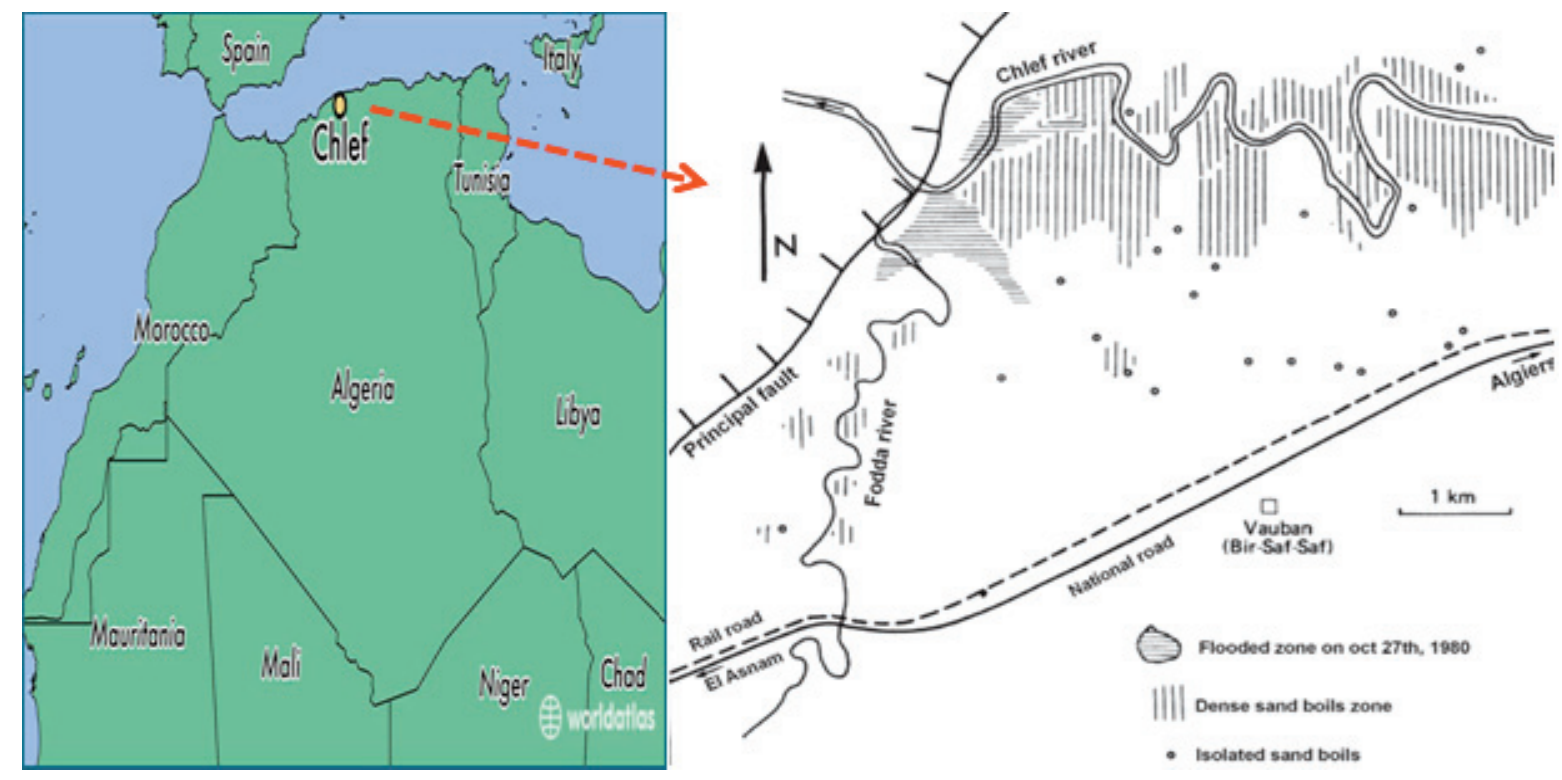

Fig. 1. Localization of the liquefaction phenomenon in Chlef valley during the earthquake of October 1980 (Durville and Méneroud [15])

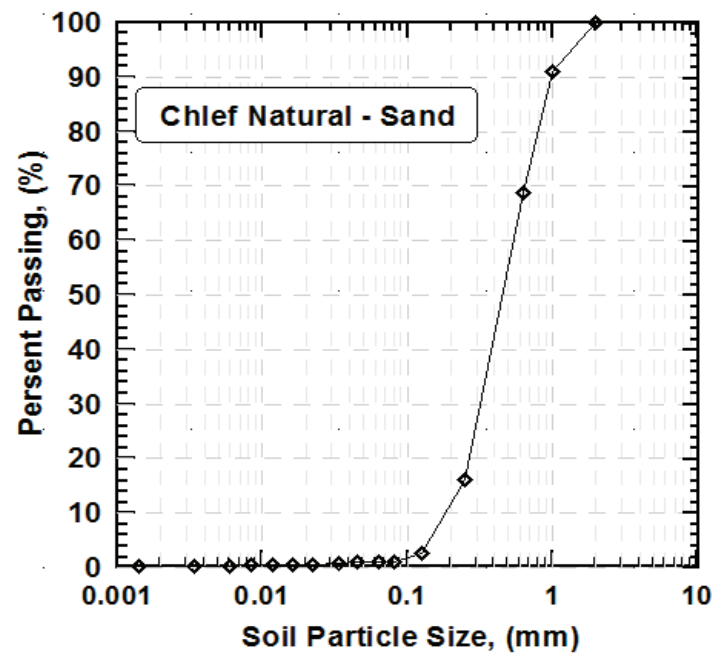

Fig. 2. Particle size distribution curve of test soil sand, which were determined according to the technical standard tests (ASTM D2487, 2000; ASTM D4253-00, 2002; ASTM D422-63, 1989) are summarized in Table 1.

Table 1. Summary of basic Chlef sand physical properties

\begin{tabular}{|l|c|}
\hline \multicolumn{1}{|c|}{ Properties of sand } & Value \\
\hline Effective size, $\mathrm{D}_{10}(\mathrm{~mm})$ & 0.182 \\
\hline Medium size, $\mathrm{D}_{50}(\mathrm{~mm})$ & 0.452 \\
\hline Uniformity coefficient, $C_{\mathrm{U}}(-)$ & 2.962 \\
\hline Coefficient of curvature, $C_{\mathrm{C}}(-)$ & 1.033 \\
\hline Specific density, $G_{\mathrm{S}}\left(\mathrm{g} / \mathrm{cm}^{3}\right)$ & 2.70 \\
\hline Maximum void ratio, $e_{\max }(-)$ & 0.98 \\
\hline Minimum void ratio, $e_{\min }(-)$ & 0.58 \\
\hline Silt plasticity index, $I_{p(\mathrm{Si})}(\%)$ & $5.5 \%$ \\
\hline
\end{tabular}



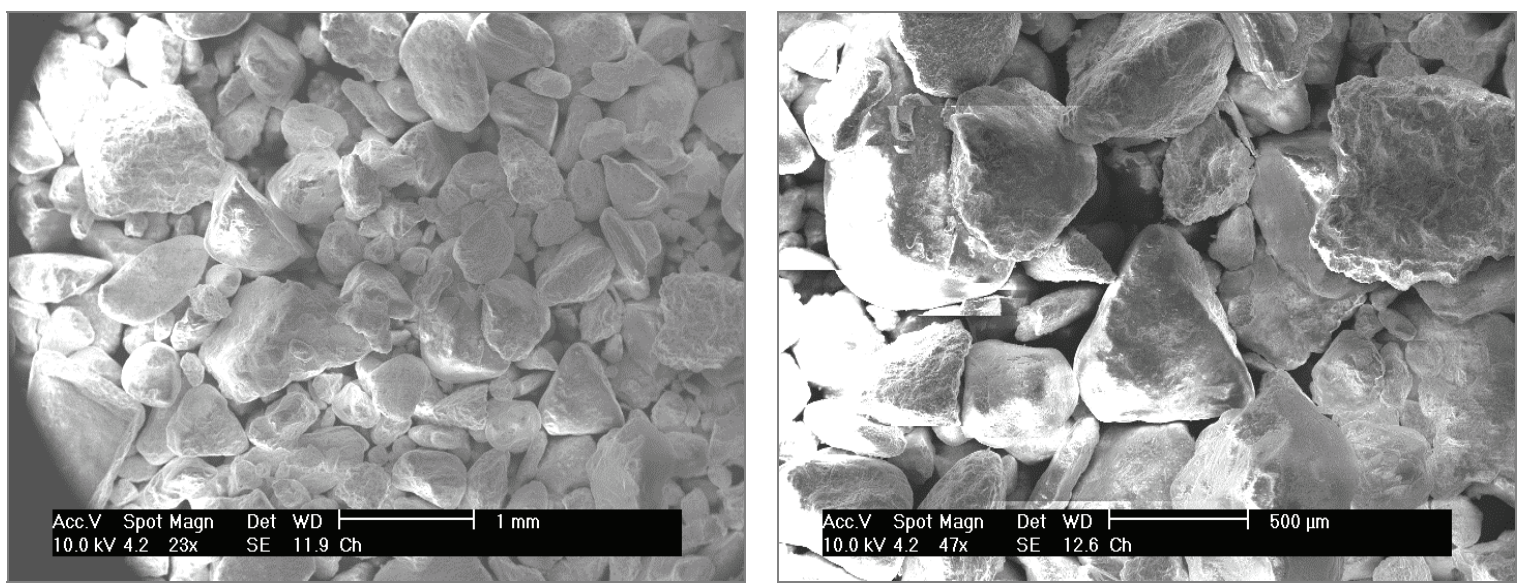

Fig. 3. Scanning electron micrograph images of the soil particles

\subsubsection{GEOTEXTILE REINFORCEMENT}

A non-woven (NW) geotextile (S41) supplied by TenCate Geosynthetics manufacturer (France) is used in these experiments. The commercial product is polypropylene based material in the form of planar layers. For this study, reinforcement layers were cut on circular form of $100 \mathrm{~mm}$ in diameter and were placed at different heights of specimen. Arrangements of one and two layers of geotextile were considered for the reinforced sample as shown in Fig. 4, while unreinforced specimen was also tested to provide a base of comparison of the effect of reinforcing material on the behaviour of soil. The physical and mechanical properties of the geotextile as obtained from data sheets attached to geotextile sold by the company are presented in Table 2.
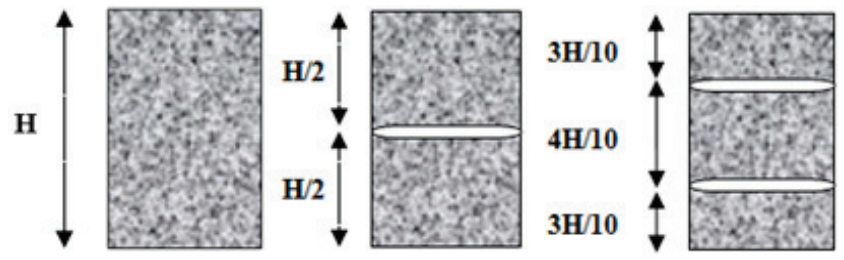

Fig. 4. Layers arrangement of geotextile on sand samples

Table 2. Physical and mechanical properties of geotextile used in the study

\begin{tabular}{|l|c|}
\hline \multicolumn{1}{|c|}{ Property } & NW-Geotextile \\
\hline Maximum tensile strength, $T_{\max }(\mathrm{kN} / \mathrm{m})$ & $12-14$ \\
\hline Permeability coefficient, $K(\mathrm{~m} / \mathrm{s})$ & $0.09-0.10$ \\
\hline Punching resistance $\mathrm{CBR}(\mathrm{kN})$ & 1.75 \\
\hline Surface weight, $W_{s}\left(\mathrm{~g} / \mathrm{m}^{2}\right)$ & 155 \\
\hline Nominal thickness, $t(\mathrm{~mm})$ & $1.60( \pm 0.10)$ \\
\hline Strain tensile strength, $\varepsilon(\%)$ & $70-90$ \\
\hline
\end{tabular}

\subsection{EXPERIMENTAL SETUP}

All the tests were conducted by Geotechnical team of Navier laboratory (CERMES) at Ecole Nationale des Ponts et Chaussées (ENPC) in France with the collaboration of the Laboratory of Materials Science and Environment (LMSE) at University Hassiba Benbouali of Chlef in Algeria. An advanced automated triaxial testing apparatus was used to conduct the monotonic undrained tests; this apparatus was also used by Feia et al. [17]. Figure 5 presents a general view of the setup showing the triaxial and the data acquisition system. The axial force is applied through a $50 \mathrm{kN}$ electromechanical press (TriScan). An internal submersible load cell of $50 \mathrm{kN}$ is used to measure the axial load. The measurement of specimen axial deformation is performed by a linear variable differential transformer (LVDT) of $50 \mathrm{~mm}$ displacement placed vertically to the cell. Pressure sensors of 1.5 MPa are used to measure the confining cell pressure and the pore pressure. The measurement of water volume change is performed by a volumeter of $100 \mathrm{~cm}^{3}$ capacity.

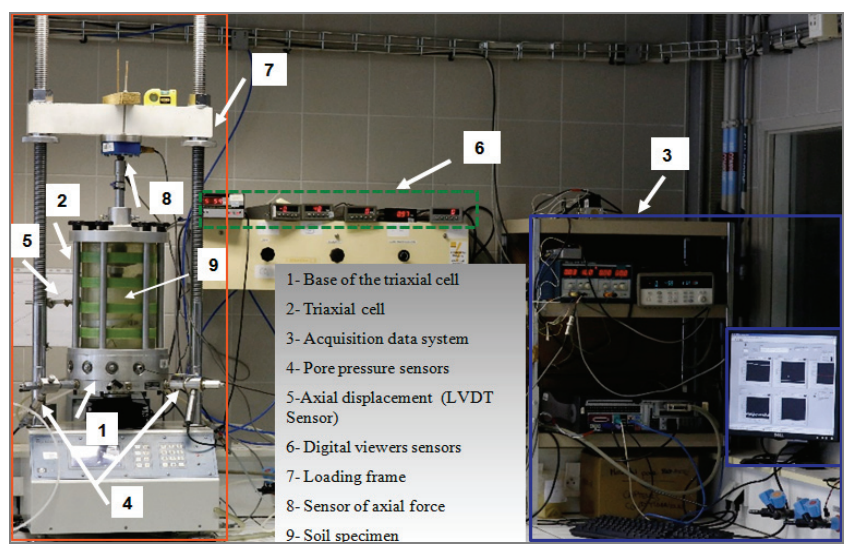

Fig. 5. View of experimental device 


\subsection{SPECIMEN PREPARATION}

Laboratory reconstituted unreinforced and reinforced sand samples with non-woven geotextile were used in this study. Triaxial tests were performed on cylindrical specimens measuring $100 \mathrm{~mm}$ in diameter by $200 \mathrm{~mm}$ in height $(\mathrm{H} / \mathrm{D}=2.0$ ) (ASTM D4767, 2011). Dry funnel pluviation method was used to prepare sand samples according to ASTM Standards. Unreinforced specimens were prepared by first estimating the dry weight of specimen corresponding to the loose density $(\mathrm{Dr}=30 \%)$, then deposited into the mold. For the reinforced specimen, after cutting the geotextile into circular forms, reinforcement inclusions are placed horizontally on the surface as each layer of sand is formed (Fig. 6), considering both the different arrangements of reinforcement layers and the relative density of sand. This study included one and two layer arrangements of geotextile positioned as shown in Fig. 4. Table 3 summarizes experimental program with illustrations of the various parameters.

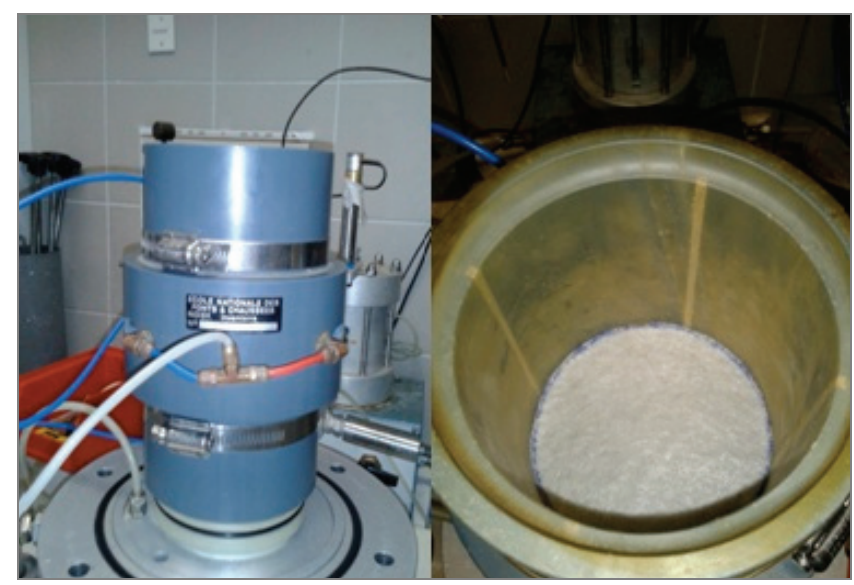

(a)

(b)

Fig. 6. Reinforced sample preparation:

(a) preparation of sand layer,

(b) geotextile emplacement into soil sample

\subsection{TEST PROCEDURE}

Consolidated undrained compression tests were performed using triaxial apparatus on both fully saturated unreinforced and reinforced sand specimens. Saturation of the specimens was accomplished by flushing with carbon dioxide for approximately $20 \mathrm{~min}$ after which de-aired water was slowly percolated through the specimen from the bottom. Moreover, the back pressure was applied to improve the degree of saturation which can be checked when the Skempton pore pressure coefficient $(B=\Delta u / \Delta \sigma)$ achieved minimum value of more than 0.95 . Following this step, the specimen is isotropically consolidated at a mean effective pressure of 50,100 and $200 \mathrm{kPa}$, and then subjected to undrained monotonic triaxial loading at a constant strain rate of $0.5 \% /$ minute. All the tests were continued up to $18 \%$ axial strain and the results were recorded using data acquisition equipment.

\section{EXPERIMENTAL RESULTS AND DISCUSSION}

\subsection{UNREINFORCED SAND}

Figure 7 shows the results of undrained monotonic compression tests of loose sand specimens without reinforcement and consolidated under confining pressures of 50,100 , and $200 \mathrm{kPa}$. The typical curves of deviatoric stress $\left(q-\varepsilon_{a}\right)$, excess pore pressure $\left(\Delta u-\varepsilon_{a}\right)$ and stress paths $\left(q-p^{\prime}\right)$ are presented. From this figure, the sample subjected to low level of confining pressure shows behaviour of limited liquefaction, where sample exhibits a limited strain softening at the beginning of the test. The rate of increase of the deviator stress is shown to be rapid at the beginning and thereafter it becomes appreciably low as axial strain is reached more than $10 \%$. However, increasing the confining pressure increases the deviator stress of sample

Table 3. Experimental program

\begin{tabular}{|c|l|l|c|c|}
\hline \multirow{2}{*}{$\begin{array}{c}\text { Test } \\
\text { loading }\end{array}$} & \multicolumn{1}{|c|}{ Samples } & \multicolumn{1}{|c|}{ Sample symbol } & $\begin{array}{c}\text { Relative density } \\
\text { Dr }(\%)\end{array}$ & $\begin{array}{c}\text { Confining pressure } \\
p_{c}^{\prime}(\mathrm{kPa})\end{array}$ \\
\hline \multirow{3}{*}{$\mathrm{CU}$} & Unreinforced & Unreinforced & $30 \%$ & $50,100,200$ \\
\cline { 2 - 5 } & One Layer of reinforcement & $1 \mathrm{~L}-\mathrm{NW}(H=6 \mathrm{~cm})$ & $30 \%$ & $50,100,200$ \\
\cline { 2 - 5 } & Two Layers of reinforcement & $2 \mathrm{~L}-\mathrm{NW}(H=6 ; 14 \mathrm{~cm})$ & $30 \%$ & $50,100,200$ \\
\hline
\end{tabular}

$\mathrm{CU}$ - consolidated undrained, NW - non-woven geotextile. 


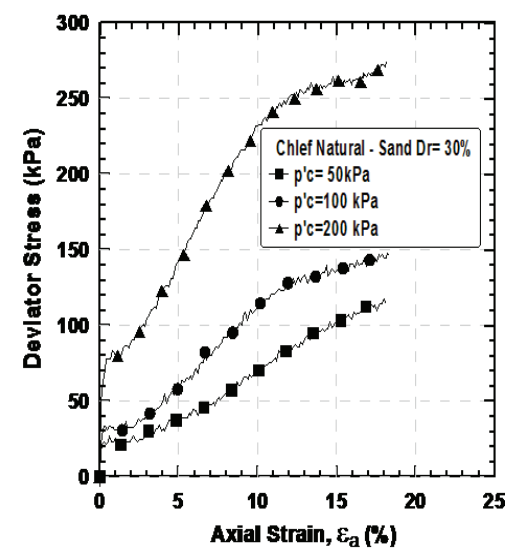

(a)

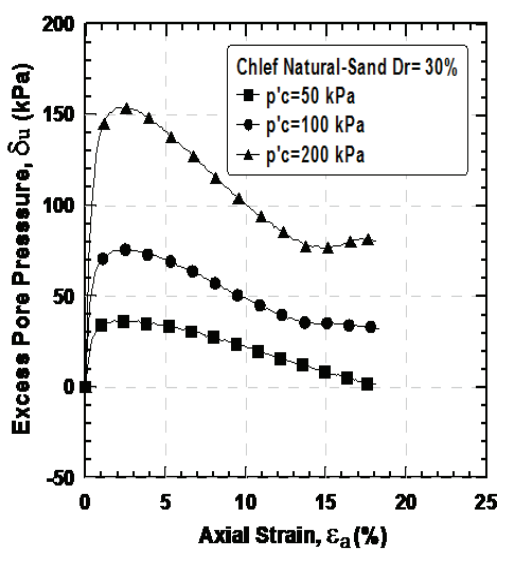

(b)

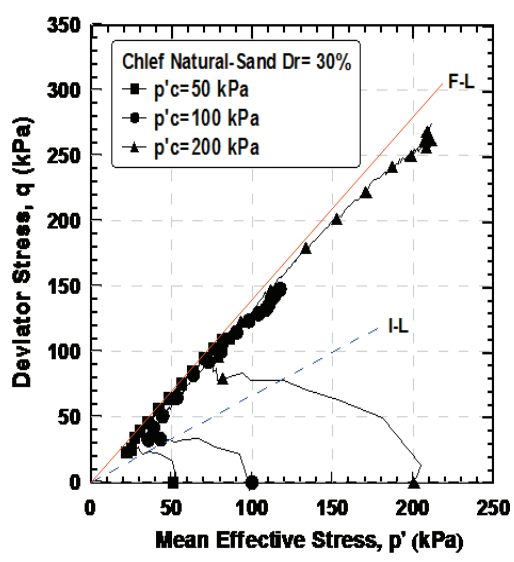

(c)

Fig. 7. Undrained response of unreinforced sand samples:

(a) deviator stress versus axial strain, (b) excess pore pressure against axial strain, (c) effective stress path

(Fig. 7a and Fig. 7c). From Fig. 7b, the pore pressure curve is found to develop firstly then followed by a decrease phase after a peak value. These increase-decrease phases are translated into contracting-dilating behaviour. It is noted that the peak pore pressure is more pronounced for the higher value of confining pressure $\left(p_{c}^{\prime}=200 \mathrm{kPa}\right)$, with a slight decrease tending to a relatively constant level than for specimen consolidated to low effective stress $\left(p_{c}^{\prime}=50 \mathrm{kPa}\right)$, which continues to drop to a low level.

\subsection{REINFORCED SAND}

\section{Variation of the deviator stress}

Typical stress-strain curves for unreinforced and reinforced specimens under confining pressures of 50,
100 , and $200 \mathrm{kPa}$, with different numbers of geotextile layers, are presented in Fig. 8a-c. Note that the reinforcement greatly increases the deviator stress especially under low confining pressure, compared with the unreinforced samples. However, for the samples reinforced with the same reinforcement configuration, the effectiveness of reinforcement decreases with increasing confining pressure (e.g., for two layers reinforcement: at $50 \mathrm{kPa}$ of confining pressure, the deviator stress increases by $97 \%$, for $100 \mathrm{kPa}$ of confining pressure, it increases by $82 \%$ ). The increase in deviator stress at $200 \mathrm{kPa}$ of confining pressure was limited $(24 \%)$, which is because, this type of geotextile is characterised by poor tensile strength at high elongation. The figures also show that the maximum deviator stress increases with the increasing number of reinforcement layers. The significant effect of the geotextile layers appears in the high strain whereas in

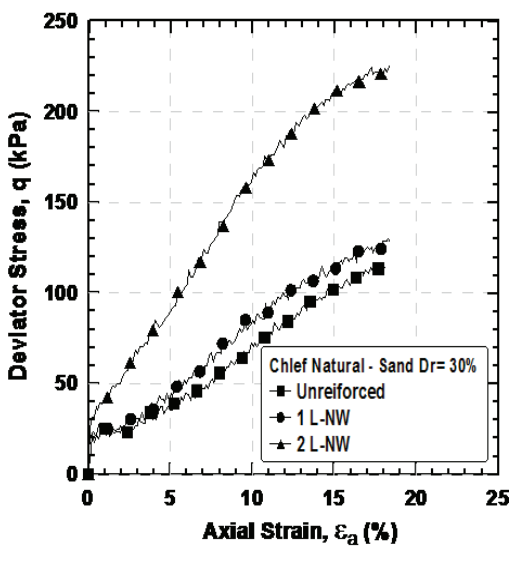

(a)

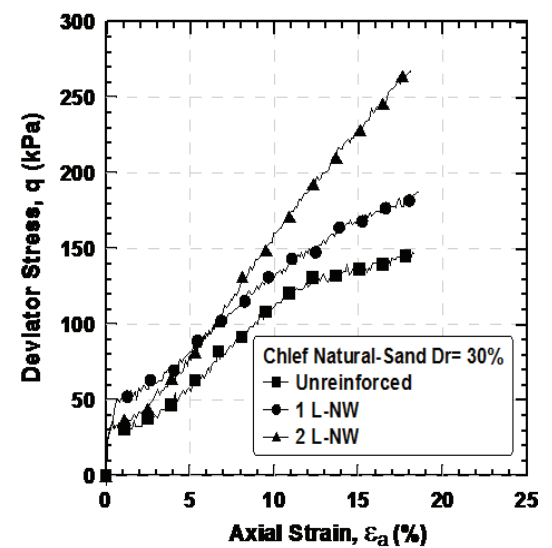

(b)

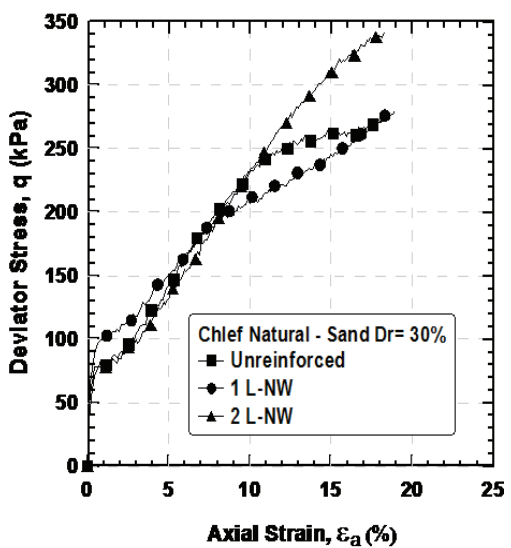

(c)

Fig. 8. Deviator stress versus axial strain curves of sand samples reinforced with various number of geotextile layers under different confining pressures: (a) $p_{c}^{\prime}=50 \mathrm{kPa}$, (b) $p_{c}^{\prime}=100 \mathrm{kPa}$, and (c) $p_{c}^{\prime}=200 \mathrm{kPa}$ 
low strain (below 5\%), where the reinforcement does not influence the behaviour of the axial stress-strain of the samples. Further, geotextile increases the ductility of sand samples. The results observed are in agreement with those reported recently by Erdogan and Altun [16], where the authors concluded that the presence of fiber reinforcement improves the soil strength and changing strain-softening stress-strain behaviour of sand samples into strain-hardening one prevents the occurrence of static liquefaction in saturated sands.

\section{Variation of the excess pore pressure}

Figure 9 illustrates the evolution of excess pore pressure of tests performed on samples of sand alone and samples reinforced either with one or two layers of geotextile. The pore pressure generation was drawn for the confining pressures of 50,100 and $200 \mathrm{kPa}$, respectively. As can be seen, curves from Fig. 9 show a similar trend, the pore pressure development and dissipation is alike for all the tests. Firstly, there is a rapid increase for the range of axial strain from $0 \%$ to $3 \%$, then followed by an important decrease after $3 \%$ axial strain and especially for low confining pressure (Fig. 9a). It was also observed that increasing reinforcement layers (2 layers) increases the peak pore pressure of reinforced samples when compared with unreinforced sand (Fig. 9b and Fig. 9c), except for the sample consolidated at confining pressure of $50 \mathrm{kPa}$, there was observed a significant reduction in excess pore pressure by adding reinforcement (Fig. 9a). Despite significant research, few attempts have been made to study the effect of confining pressure on the undrained behaviour of reinforced soil in planar form, and particularly on the pore pressure response of reinforced sand with geotextile layers.
Tuna et al. [34] in their experimental work have reported similar results, indicating that when compared at the same initial relative density, the use of geotextile reduces dilation especially at higher confining pressure. Chen et al. [12] have concluded that inclusion of geogrid reinforcement increases the peak pore pressure of coarse grained soil with a limited effect of confining pressure. Kim et al. [23] have found that geotextile layers reduce the dilatancy of dense sand. Chen and Loehr [11] observed in their laboratory works that the pore pressure response of fiber reinforced sand depends mainly on initial density of soil samples subjected to low confining pressure.

In fact, increasing confining pressure reduces the dilatancy of unreinforced samples, which was also observed on the pore pressure development and dissipation curves of reinforced sand. This explains mainly the relationship between the geotextile and the higher confining pressure. As seen in Figs. 8 and 9, reinforced samples exhibit high deviator stress with low dissipation phase in the pore pressure, inversely unreinforced samples present a minimum deviator stress and important decrease on the pore pressure when compared to reinforced samples.

\section{Strength properties}

The effective stress paths of undrained monotonic triaxial tests are plotted in Fig. 10. As can be seen from this figure, geotextile inclusion reduces the contractive behaviour of samples at low stress levels (Fig. 10a) and as expected, increasing confining pressure amplified the contractancy of reinforced sand, especially for samples reinforced with 2 layers of geotextile. This contractancy is the result of an incremental increase of confining pressure that led to re-

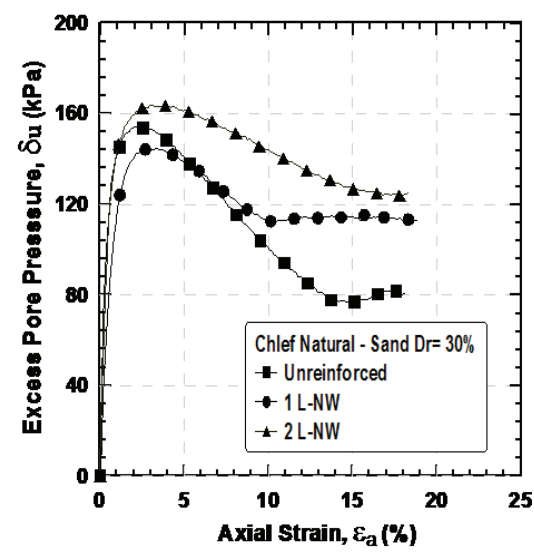

(a)

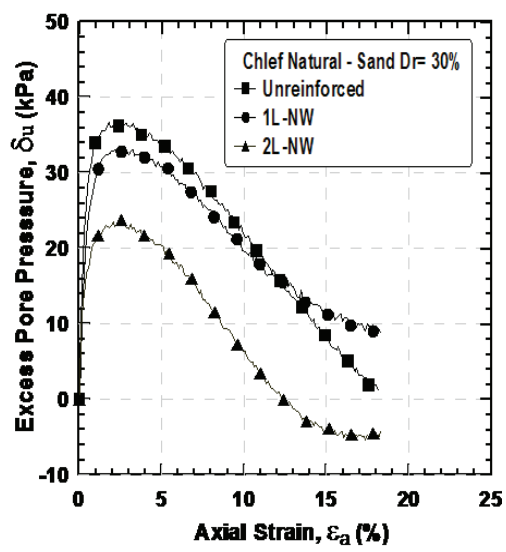

(b)

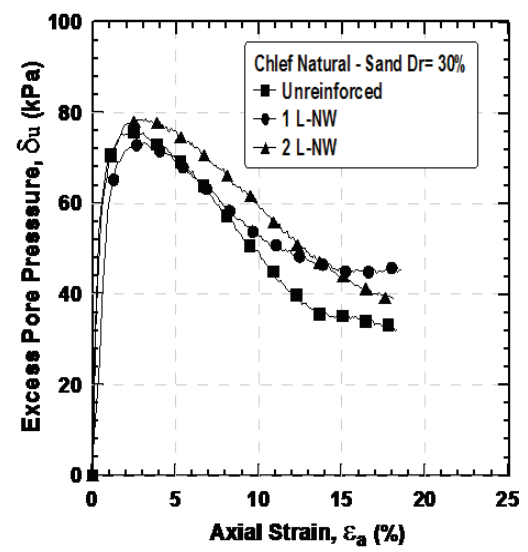

(c)

Fig. 9. Excess pore water pressure versus axial strain curves of sand reinforced with various number of geotextile layers under different confining pressures: (a) $p_{c}^{\prime}=50 \mathrm{kPa}$, (b) $p_{c}^{\prime}=100 \mathrm{kPa}$, and (c) $p_{c}^{\prime}=200 \mathrm{kPa}$ 


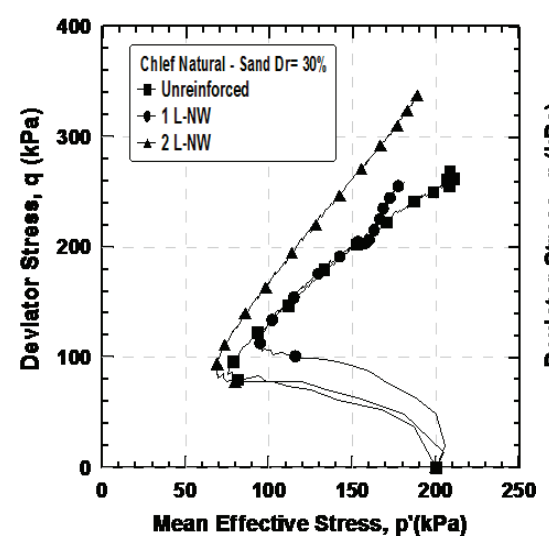

(a)

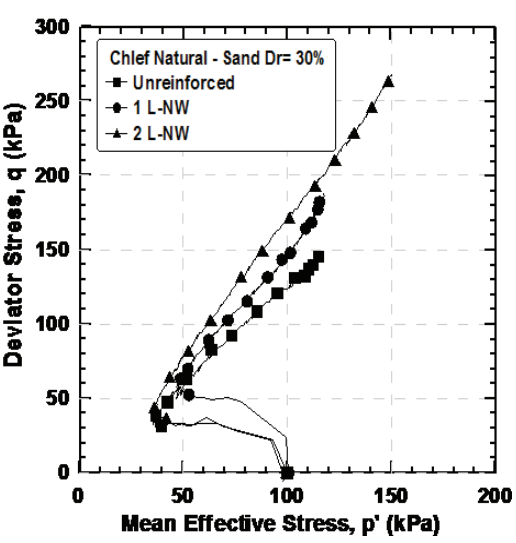

(b)

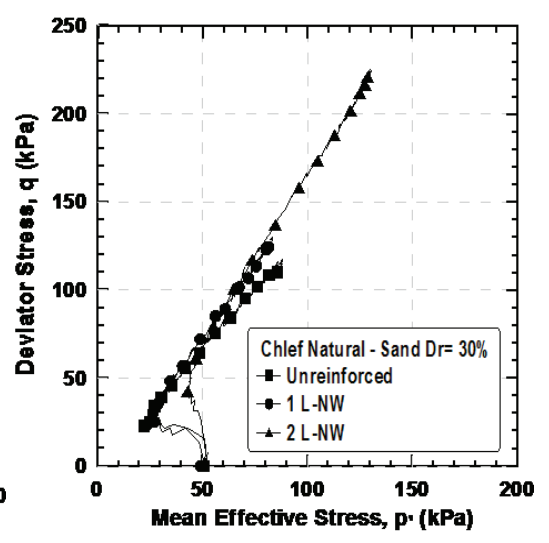

(c)

Fig. 10. Effective stress path curves of sand unreinforced and reinforced with various number of geotextile layers under different confining pressures: (a) $p_{c}^{\prime}=50 \mathrm{kPa}$, (b) $p_{c}^{\prime}=100 \mathrm{kPa}$, and (c) $p_{c}^{\prime}=200 \mathrm{kPa}$

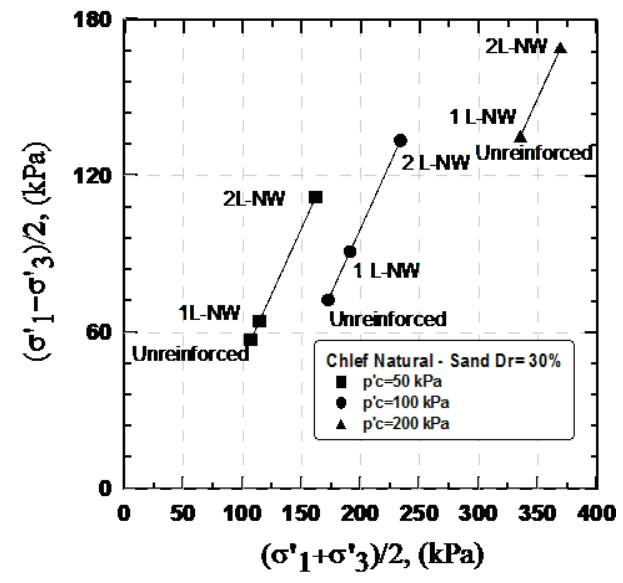

Fig. 11. $\left(\sigma_{1}-\sigma_{3}\right) / 2$ versus $\left(\sigma_{1}-\sigma_{3}\right) / 2$ envelopes plot of geotextile reinforced samples at the end of tests (18\% axial strain) striction of the mobilized surface between reinforcement and soil (decreasing void ratio) and to initiation of deformability reinforcement (Figs. 10b-c). In addition, there can be shown the role of reinforcement to increase dilation tendency of reinforced samples at low confining pressure, where an important increase in the mean effective and deviator stresses has occurred by adding reinforcement layers.

Figure 11 shows the $\left(\sigma_{1}^{\prime}-\sigma_{3}^{\prime}\right) / 2$ versus $\left(\sigma_{1}^{\prime}+\sigma_{3}^{\prime}\right) / 2$ envelopes plot of geotextile reinforced samples at $18 \%$ axial strain. As indicated in this figure, the envelopes of all specimens are linear and relatively parallel. The values of such strength parameters as cohesion and friction angle calculated from Fig. 11 are presented in Table 4. It is noted that the cohesion increases with increasing number of geotextile layers,

Table 4. Strength parameters values for unreinforced and reinforced sand versus axial strain

\begin{tabular}{|c|c|c|c|c|c|c|}
\hline $\begin{array}{c}\text { Axial strain } \\
(\%)\end{array}$ & \multicolumn{3}{|c|}{$\begin{array}{c}\text { Cohesion } \\
C^{\prime}(\mathrm{kPa})\end{array}$} & \multicolumn{3}{c|}{$\begin{array}{c}\text { Friction angle } \\
\Phi^{\prime}\left({ }^{\circ}\right)\end{array}$} \\
\hline Samples & Unreinforced & One layer & Two layers & Unreinforced & One layer & Two layers \\
\hline 18 & 16.36 & 28.71 & 68.24 & 19.29 & 17.69 & 15.32 \\
\hline
\end{tabular}
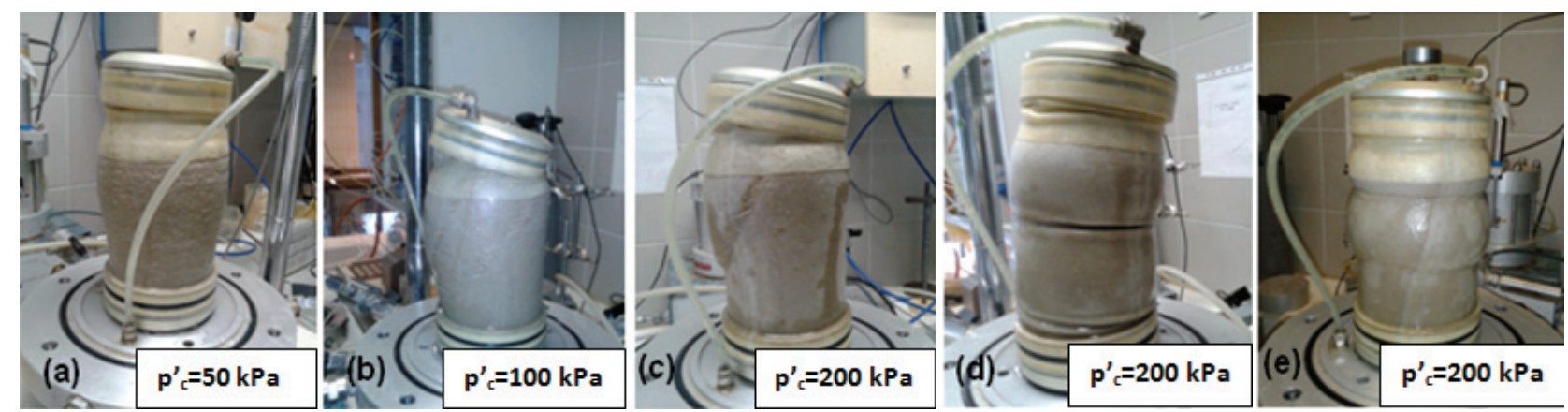

Fig. 12. Photographs of specimens after shearing: (a), (b) and (c) unreinforced specimens, (d) one layer reinforced specimen, and (e) two layer reinforced specimen 
whereas the friction angle tends to decrease. These trends were also mentioned by Latha and Murthy [25] and Erdogan and Altun [16] and can be attributed to the role of reinforcement to interlock the soil particles, reducing the number of contact points between the layers of soil particles.

Figure 12 shows photographs of test specimens after shearing. Specimens showed instability with shear band formation on unreinforced specimen subjected to levelling up of confining pressure (Fig. 12a, b and c). For reinforced specimen, geotextile inclusion increases the confinement of specimen leading to an increase in the deformation of specimens (Fig. 12d-e), reinforced specimens showed the formation of bulging deformation up the layers of reinforcement position without any shear band rupture.

\section{Sand-geotextile strength ratio}

The performance of geotextile inclusions on sand samples behaviour is shown in Fig. 13, where the strength ratio parameter (SR) is defined as the ratio of the maximum deviator stress of reinforced sand $\left(q_{\max }^{\mathrm{R}}\right)$ to the maximum deviator stress of unreinforced sand $\left(q_{\max }^{\mathrm{Ur}}\right)$ as calculated by (Latha and Murthy [25])

$$
S R=\left(q_{\max }^{\mathrm{R}} / q_{\max }^{\mathrm{Ur}}\right) .
$$

Table 5 summarizes the values of maximum deviator stress and corresponding values of the strength ratio of all the tests. The obtained results indicate that the strength ratio increases with increasing geotextile layers and as shown in Fig. 13a, b, where it is observed that specimens reinforced with two geotextile layers exhibited more strength than sand alone or with one layer of reinforcement. Considering the effect of confining pressure, all reinforced specimens present a strength ratio superior or equal to 1 , however Fig. 13b demonstrates an important decrease of the strength ratio with increasing confining pressure, e.g., the strength ratio of samples with two layers of reinforcement are 1.97, 1.82 and 1.24 for confining pressures of 50,100 and $200 \mathrm{kPa}$, respectively. In general, geotextile improves the shear strength of Chlef sand

Table 5. Maximum deviator stress and strength ratio values of experimental program

\begin{tabular}{|l|c|c|c|}
\hline \multirow{3}{*}{ Specimens } & $p_{c}^{\prime}(\mathrm{kPa})$ & $q_{\max }(\mathrm{kPa})$ & $\mathrm{SR}(-)$ \\
\hline \multirow{3}{*}{ Unreinforced } & 50 & 114.71 & - \\
\cline { 2 - 4 } & 100 & 147.86 & - \\
\cline { 2 - 4 } & 200 & 275.01 & - \\
\hline \multirow{3}{*}{$1 \mathrm{~L}-\mathrm{NW}$} & 50 & 129.91 & 1.13 \\
\cline { 2 - 4 } & 100 & 187.47 & 1.27 \\
\cline { 2 - 4 } & 200 & 280.43 & 1.02 \\
\hline \multirow{3}{*}{ L-NW } & 50 & 226.03 & 1.82 \\
\cline { 2 - 4 } & 100 & 286.47 & 1.24 \\
\cline { 2 - 4 } & 200 & 341.73 & \\
\hline
\end{tabular}

Note: $q_{\max }=$ Maximum Deviator Stress, $\mathrm{SR}=$ The Strength Ratio

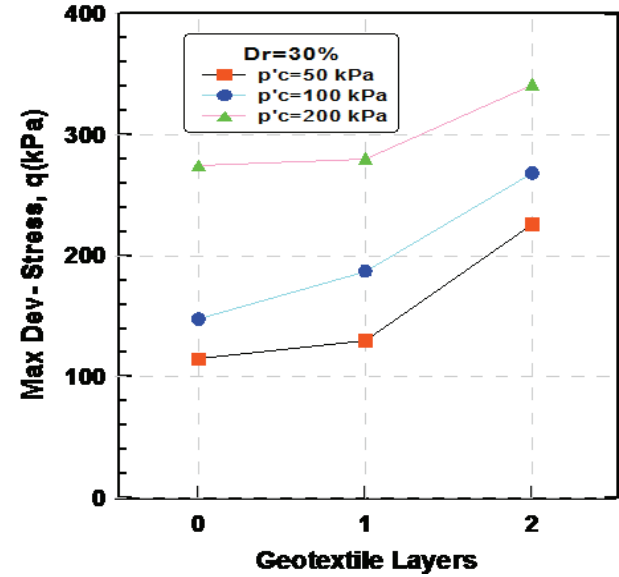

(a)

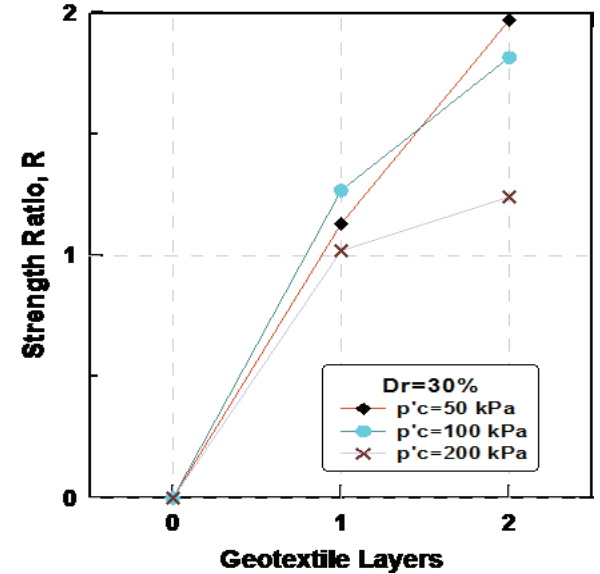

(b)

Fig. 13. Maximum deviator stress and strength ratio versus geotextile layers for different confining pressures 
especially under lower confining pressures. These results are in perfect agreement with those given by Zhang et al. [37] and Chen et al. [12].

\section{CONCLUSIONS}

A series of triaxial compression tests were performed to study the undrained behaviour of unreinforced and reinforced sand with non-woven geotextile. The purpose of this study was to investigate the effect of initial confining pressure and geotextile reinforcement on the behaviour of sand. The main conclusions from the present study can be summarized as follows:

(1) The presence of geotextile enhances the behaviour of sand samples, the obtained results show that reinforced samples exhibit a continued increase in shear resistance by adding up layers of reinforcement; in addition, failure envelope was found to need more axial strain when compared to the unreinforced samples, particularly no noticeable peak stress at strain was observed up to $18 \%$ for reinforced samples.

(2) The effect of reinforcement is visible only under the lowest confining pressure. The geotextile type of reinforcement used is characterized by poor tensile strength at high elongation; the higher value of confining pressure reduces the reinforced sand dilatancy and the more effect of reinforcement efficiently.

(3) It seems that the confining pressure has a large effect on the pore pressure variation, as seen that the increase on confining pressure limits the dissipation phase and increases the excess pore pressure development of sand samples with and without geotextile.

(4) From the $q-p^{\prime}$ stress path, it is observed that geotextile reinforcement improves the cohesion strength of reinforced soil, and reduces the internal friction angle by decreasing the number of contact points between the soil particles.

(5) Both pore pressure evolution and strength ratio of reinforced sand are strongly affected by the initial stress levels. Indeed the increase in confining pressure increases the pore pressure and reduces the strength ratio.

\section{REFERENCES}

[1] Ahmed F., Bateni F., Mastura A., Performance evaluation of silty sand reinforced with fibers, Geotextiles and Geomembranes, 2009, 28(1), 93-99, DOI: 10.1016/j.geotexmem.2009.09.017.
[2] Al Refeai T.O., Behavior of granular soils reinforced with discrete randomly oriented inclusions, Geotextiles and Geomembranes, 1991, 10(4), 319-333, DOI: 10.1016/0266-1144(91)90009-L.

[3] Arab A., Sadek M., Belkhatir M., Shahrour I., Monotonic Preloading Effect on the liquefaction resistance of Chlef silty sand: A Laboratory Study, Arabian Journal For Science and Engineering, 2013, 39(2), 1-10, DOI: 10.1007/s13369-013-0700-4.

[4] ASTM D2487, Standard practice for classification of soil for engineering purposes. (Unified Soil Classification System), Annual Book of ASTM Standards, 2000, Vol. 04.08, ASTM, Philadelphia, www.astm.org

[5] ASTM D4253-00, Standard test method for maximum index density and unit weight of soils using a vibratory table, Annual Book of ASTM Standards. American Society for Testing and Materials, West Conshohocken, PA, 2002, 1-14, www.astm.org

[6] ASTM D422-63, Standard method for particle-size analysis of soils, Annual Book of ASTM Standards, 1989, Vol. 04.08, 86-92. West Conshohoken, www.astm.org

[7] ASTM D4767, Standard test method for consolidated undrained triaxial compression test for cohesive soils, ASTM International, West Conshohocken, PA, 2011, www.astm.org

[8] Belkhatir M., Della N., Arab A., Schanz T., Laboratory Study on the Hydraulic Conductivity and Pore Pressure of Sand-Silt Mixtures, Marine Georesources and Geotechnology, 2014, 32(2), 106-122, DOI: 10.1080/1064119X.2012.710712.

[9] Benghalia Y., Bouafia A., Canou J., Dupla J.C., Liquefaction susceptibility study of sandy soils: effect of low plastic fines, Arab. Journal of Geosciences, 2014, 8(2), 605-618, DOI: $10.1007 / \mathrm{s} 12517-013-1255-0$.

[10] CHEN C.W., Drained and undrained behavior of fiberreinforced sand, Midwest Transportation Consortium of Student Papers, Transportation Scholars Conference, Iowa State University, Ames, Iowa, 2006.

[11] CHEN C.W., LoEHR J.E., Undrained and drained triaxial tests of fiber-reinforced sand, Proceedings of the 4th Asian Regional Conference on Geosynthetics Shanghai, China, 2008.

[12] CHEN X., ZHANG J., Li Z., Shear behaviour of a geogridreinforced coarse-grained soil based on large-scale triaxial tests, Geotextiles and Geomembranes, 2014, 42(4), 312-328, DOI: 10.1016/j.geotexmem.2014.05.004.

[13] Consoli N.C., Vendruscolo M.A., Fonini A., Dalla Rosa F., Fiber reinforcement effects on sand considering a wide cementation range, Geotextextiles and Geomembranes, 2009, 27 (3), 196-203, DOI: 10.1016/j.geotexmem.2008.11.005.

[14] Della N., Belkhatir M., Arab A., Canou J., Dupla J.C., Effect of fabric method on instability behavior of granular material, Acta Mechanica, 2014, 225(7), 1-15, DOI: 10.1007/s00707-013-1083-z.

[15] Durville J.L., Meneroud J.P., Phenomenes geomorphologiques induits par le seisme d'El-Asnam, Algerie. Bull. Liaison Labo. P. et Ch., 120, juillet-aout, 1982, 13-23.

[16] ERdogan D., Altun S., Undrained response of loose fiber reinforced sand, C.B.Ü. Journal of Science and Technology, 2015, 11(1), 7-16, DOI: 10.18466/cbufbe.82988.

[17] Feia S., Sulem J., Canou J., Ghabezloo S., Clain X., Changes in permeability of sand during triaxial loading: effect of fine particles production, Acta Geotechnica, 2014, 11(1), 1-19, DOI: 10.1007/s11440-014-0351-y.

[18] Gray D.H., OHASHi H., Mechanics of fiber reinforcement in sand, Journal of Geotech. Eng., 1983, 109(3), 335-353, DOI: 10.1061/(ASCE)0733-9410(1983)109:3(335). 
[19] Haeri S.M., Noorzad R., Oskoorouchi A.M., Effect of geotextile reinforcement on the mechanical behavior of sand, Geotextiles and Geomembranes, 2000, 18(6), 385-402, DOI: 10.1016/S0266-1144(00)00005-4.

[20] HAMIDI A., HoORESFAND M., Effect of fiber reinforcement on triaxial shear behavior of cement treated sand, Geotextiles and Geomembranes, 2013, 36, 1-9, DOI: 10.1016/j.geotexmem.2012.10.005.

[21] HosseinPour I., Mirmoradi S.H., BARARI A., OMIDVAR M., Numerical evaluation of sample size effect on the stress-strain behavior of geotextile-reinforced sand, Journal of Zhejiang, 2010, 11(8), 555-562, DOI: 10.1631/jzus.A0900535.

[22] Ibraim E., Diambra A., Muir Wood D., Russell AR., Static liquefaction of fibre reinforced sand under monotonic Loading, Geotextiles and Geomembranes, 2010, 28(4), 374-385, DOI: 10.1016/j.geotexmem.2009.12.001.

[23] Кім Y.S., Он S.W., Сно D.S., Effect of non-woven geotextile reinforcement on mechanical behavior of sand, J. Korean Geosynthetics Society, 2010, 9, 39-45.

[24] KRISHNASWAMY N.R., ISAAC N.T., Liquefaction potential of reinforced sand, Geotextiles and Geomembranes, 1994, 13(1), 23-41, DOI:10.1016/0266-1144(94)90055-8.

[25] LAtha M.G., MuRTHY V.S., Effects of reinforcement form on the behavior of geosynthetic reinforced sand, Geotextiles and Geomembranes, 2007, 25(1), 23-32, DOI: 10.1016/j.geotexmem.2006.09.002.

[26] LAtHA M.G., MuRThy S.V., Investigation on sand reinforced with different geosynthetics, Geotechnical Testing Journal, 2006, 29(6), DOI: 10.1520/GTJ100439.

[27] Liu J., Wang G., Kamai T., Zhang F., Yang J., Shi B., Static liquefaction behavior of saturated fiber-reinforced sand in undrained ring-shear tests, Geotextiles and Geomembranes, 2011, 29(5), 462-471, DOI: 10.1016/j.geotexmem. 2011.03.002.
[28] NAeini S.A., Khalaj M., IZADI E., Interfacial shear strength of silty sand-geogrid composite, Geot. Eng., 2013, 166(1), 67-75, DOI: 10.1680/geng.10.00118.

[29] NAEINI S.A., GHOLAMPOOR N., Cyclic behavior of dry silty sand reinforced with a geotextile, Geotextiles and Geomembranes, 2014, 42(6), 611-619, DOI: 10.1016/j.geotexmem.2014.10.003.

[30] NoORZAD R., FARDAD AMINI P., Liquefaction resistance of Babolsar sand reinforced with randomly distributed fibers under cyclic loading, Geotextiles and Geomembranes, Soil Dynamics and Earthquake Engineering, 2014, 66, 281-292, DOI: 10.1016/j.soildyn.2014.07.011.

[31] Nouri S., NechneCh A., LAMri B., LuRdes Lopes M., Triaxial test of drained test reinforced with plastic layers, Arab. J. Geosci., 2015, 9(1), 1-9, DOI 10.1007/s12517-015-2017-y.

[32] Rajagopal K., Krishnaswamy N.R., Latha M.G., Behaviour of sand confined with single and multiple geocells. Geotextiles and Geomembranes, 1999, 17(3), 171-184, DOI: 10.1016/S0266-1144(98)00034-X.

[33] RANJAn G., VASAn R.M., ChaRAN H.D., Behavior of plastic fiber-reinforced sand, Geotextiles and Geomembranes, 1994, 13(8), 555-565, DOI:10.1016/0266-1144(94)90019-1.

[34] TUNA S.C., KARAKAN E., AltUN S., Mechanical behaviour of geotextile reinforced sand, Imo Teknik Journal, 2015, 26, 7015-7022.

[35] Venkatappa Rao G., Dutta R.K., Ujwala D., Strength Characteristics of Sand Reinforced with Coir Fibres and Coir Geotextiles, Electronic Journal of Geotechnical Engineering, USA, 2005, 10/G, http://www.ejge.com

[36] Yetimoglu T., Salbas O., A study on shear strength of sands reinforced with randomly distributed discrete fibers, Geotextiles and Geomembranes, 2003, 21(2), 103-110, DOI: 10.1016/S0266-1144(03)00003-7.

[37] ZHANG M.X., JAVADI A.A., MIN X., Triaxial tests of sand reinforced with $3 D$ inclusions, Geotextiles and Geomembranes, 2006, 24(4), 201-209, DOI: 10.1016/j.geotexmem.2006.03.004. 